\title{
Efeito da presença de líquido amniótico em culturas de fibroblastos humanos fetais
}

\author{
Effect of amniotic fluid presence in cultures of fetal human fibroblasts
}

\section{Acadêmica: Leticia Hitomi Yagi \\ Orientadores: Cesar Isaac, Gabriel Carvalho, Rolf Gemperli}

Introdução: Fetos humanos, em fase precoce de gestação, respondem às lesões cutâneas com regeneração da pele. A provável explicação para tal fato pode decorrer do aumento de colágeno tipo III por fibroblastos fetais, alteração da razão entre fatores transformadores de crescimento beta 1 e 3 (bTGF3/ bTGF1), levando a diminuição de colágeno tipo I; aumento da produção de miofibroblastos (conforme o período gestacional) com maior capacidade de migração e proliferação dessas células. O fator de crescimento de fibroblastos beta (bFGF) no líquido amniótico está relacionado à maior proliferação celular.

Objetivo: Avaliamos fibroblastos presentes no líquido amniótico de gestantes humanas quanto a proliferação in vitro, síntese de colágenos I e III e expressão de bTGF quando cultivados na presença e ausência de líquido amniótico.

Método: Fibroblastos fetais foram cultivados em ALFA-MEM $+1 \%$ de estreptomicina $(100 \mu \mathrm{g} / \mathrm{mL}) / \mathrm{penicilina}(100$ $\mathrm{UI} / \mathrm{mL})$ / anfotericina B $(0,25 \mu \mathrm{g} / \mathrm{mL}), 1 \%$ de L-glutamina e $20 \%$ de soro bovino fetal (SBF). A proliferação celular foi avaliada pelo teste de absorbância com MTT. VEGF, Pró-colágeno I, Pró- colágeno III e bTGF foram avaliados por qPCR.

Resultados: Fibroblastos mantidos em SBF + ALFA MEM mostraram maior expressão de VEGF, enquanto o estímulo com líquido amniótico (LA) mostrou maior expressão de Pró-colágeno I. A adição de líquido amniótico ao meio de cultivo padrão potencializou a expressão de bTGF. A proliferação celular, independentemente do estímulo realizado, apresentou tendência linear.

Conclusão: SBF nas culturas de fibroblastos fetais estimula neoangiogênese. Enquanto LA induz a expressão de fatores envolvidos no processo de cicatrização.

Palavras-chave: Fibroblastos; Cicatrização; Líquido amniótico; Feto; Peptídeos e proteínas de sinalização celular.

Introduction: Human fetuses, in early gestation, respond to skin lesions with regeneration. A likely explanation for these fact may be related to factors such as increased type III collagen synthesis by fetal fibroblasts; change in the ratio of beta transforming growth factors 1 and 3 (bTGF3 / bTGF1), due to a reduction of type I collagen; increased production of myofibroblasts (according to the pregnancy phase) and higher capacity of fibroblasts proliferation and migration. The fibroblast growth factor beta (bFGF) is related to increase of cellular proliferation.

Objective: Fibroblasts presented in human pregnants' amniotic fluid were tested to show in vitro proliferation, collagen I and III production and bTGF expression, all situations cultivated in presence or absence of amniotic fluid. Method: fetuses fibroblasts were cultivated on ALFA-MEM $+1 \%$ of streptomycin $(100 \mu \mathrm{g} / \mathrm{mL}) /$ penicillin $(100 \mathrm{UI} / \mathrm{mL}) / \mathrm{amphotericin}$ B $(0,25 \mu \mathrm{g} / \mathrm{mL}), 1 \%$ of L-glutamine and $20 \%$ of fetal bovine serum (SBF). The cellular proliferation was evaluated by absorbance test with MTT. VEGF, pro- collagen I, pro- collagen III and bTGF, were tested by qPCR. 
Results: Fibroblasts containing fetal bovine serum + ALMA MEM showed best expression of VEGF, while fibroblasts with amniotic fluid (LA) showed best expression of pro- collagen I. The addition of amniotic fluid using standard cultivation potentiated the expression of bTGF. Cellular proliferation regardless of the stimulus conducted showed a linear trend.

Conclusion: SBF in fetus fibroblasts cultures stimulates neoangiogenesis. However, LA without SBF induces factors expression involved in healing process.

Keywords: Fibroblasts; Wound healing; Amniotic fluid; Fetus; Intercellular signaling peptides and proteins. 